\title{
Insulin Resistance Measurement
}

National Cancer Institute

\section{Source}

National Cancer Institute. Insulin Resistance Measurement. NCI Thesaurus. Code C123458.

The determination of the insulin resistance (cells inability to respond to insulin) in a biological specimen. 